\title{
Governance and Performance of National Government-Constituencies Development Funds in Kenya
}

\author{
Charles Thomas Keya, PhD Student, \\ Prof. Josiah Aduda, \\ Dr. Winnie Nyamute, \\ Prof. Ganesh Pokhariyal, \\ University of Nairobi, Kenya
}

Doi:10.19044/esj.2020.v16n10p154 URL:http://dx.doi.org/10.19044/esj.2020.v16n10p154

\begin{abstract}
The main objective of the study was to establish the relationship between governance and performance of National GovernmentConstituencies Development Funds (NG-CDFs) in Kenya. A census survey was carried out on all the 290 NG-CDFs performance in Kenya. A positivistic research philosophy and a descriptive cross-sectional survey design were used. Data was collected using structured and unstructured questionnaire. Secondary data was easily accessible from the National Treasury, Kenya National Bureau of Statistics, the General Auditor's reports and NG-CDF website and was collected for the period 2014 to 2018. Simple regression analysis was used to test the hypotheses at 95 percent confidence level. The results of the study were established and compared to various theories anchoring the study and conceptual, contextual and empirical evidence. It was established that there is a statistically significant relationship between governance and NG-CDFs performance in Kenya. The study benefits policy makers such that the NG-CDF board should ensure that all NG-CDFs have homogeneous governance practices that ensure enhanced performance. Managerial practitioners especially in NG-CDF may consider strengthening governance to enhance performance and use Data Envelopment Analysis (DEA) technique to measure performance in NG-CDFs.
\end{abstract}

Keywords: Governance and Performance of NG-CDFs

\section{Introduction}

Governance are policies, laws and regulations that direct the way an organization is managed and controlled resulting to transparency as well as 
objectivity in the relationship between the entity and the owners that contain both internal and external contracts between employees and the owners that enhance harmony for improved performance (Buallay et al.,2017).According to Okiro (2014), governance is the system that promotes and enhances efficiency, transparency and accountability of an organization that regards compliance with the law and proper utilization and management of organizational resources. In accordance to World Bank (1992), governance is the sound development management that needs techniques of information disclosure, transparency, organizational structure, accountability, legal frame work and sufficient and dependable information public service delivery and efficient resource allocation.

Good governance is mainly concerned with the rule of law, participation of the relevant parties, full disclosure, transparency, installation of structures, equity and inclusiveness, accountability, efficiency and effectiveness (Okiro, 2014).The researcher of the study describes governance as a technique comprising a set of regulations and laws, responsibilities and practices which guide and give strategic direction to assure risks are managed; objectives are attained and resources have been used responsibly and there is transparency, disclosures, structures in an organization and accountability to enhance performance.

Indicators of governance used by the researcher are organizational structures, transparency and disclosures. Organizational structures are the frameworks and pillars for practicing corporate governance (Semmar, 2012). They are the mechanisms for decisions making that are not clearly particular in initial contract between managers and owners and once put in place they enhance performance (Formentini \& Taticchi, 2016). Transparency is essentially about the availability of information for all the players such as agents, owners, firm and other partners (Hebb, 2006). It has various parts: financial disclosures, governance transparency and performance transparency (Bushman et al. 2004). According to McGee and Yuan (2009), it further incorporates disclosure of pertinent information about a firm's methods of corporate governance, its operational as well as financial performance. On the other hand, disclosure is the openness in the organisation's conduct of its business activities (OECD, 2004). It provides all sufficient information about the entity. Some studies found that good governance enhances performance (Tariq \& Abbas 2013) others found that governance had a negative relationship between governance and entity's performance (Price et al., 2011).

Governance is important to an organization because it installs organizational structures and procedures for making decisions, accountability, regulation and behavior at the organizations (Armstrong et al., 2005). Good governance ensures that processes and techniques that encourage required behavior are executed by organizations (Braadbaart, 2007). The action 
prompts organizations to create as well as implement instructions and practice manuals which help the organization to adopt a culture which encourages responsibility, accountability and transparency which results to enhanced performance (Braadbaart, 2007). According to Arena et al., (2015) performance refers to organizational effectiveness, efficiency, financial viability and relevance. Organizational performance may be measured by various methods that consider cost of operations and the benefits arising there from. The specific methods are cost effective analysis, and the Data Envelopment Analysis (DEA) as suggested by Tavana et al. (2016). DEA technique is mostly vigorous than the other techniques given the fact that it measures performance considering several inputs and output variables (Ndimitu et al., 2018). DEA model is a non-parametric method which evaluates performance of Decision Making Units (DMU) as per ratios that utilize several inputs to generate numerous output (Emrouznejad et al., 2010).

Performance of NG-CDFs in Kenya is measured using DEA model based on consumer rights and standards requirements by the Constitution of Kenya which include the following key performance indicators: Customer satisfaction survey, compliance with budget levels, safety measures, utilization of allocated funds, project implementation, compliance with strategic plan, development of service charter, corruption eradication, disposal of idle assets, employee satisfaction survey, HIV/AIDS behavioral change, fulfillment of statutory obligations; repair and maintenance (GoK, 2010). In the research, DEA Model inputs were: budget allocations, projects approved, operational costs incurred and employee remunerations. The outputs were projects completed, projects efficiency, employee efficiency and operational efficiency. Customer satisfaction in NG-CDFs is achieved through the fulfillment of the output that reflect quality education and security services that citizens of the constituency get from NG-CDFs. Education and security quality services are measured for example by the number of projects completed as per schedule and reduction in crimes. Performance of NG-CDFs is computed to reflect efficiency in terms of the output- input ratio.

The origin of NG-CDF was the CDF Act (2003) and revised in 2013, 2015 and 2016. Through the Act 2016 of parliament its name changed from CDF to NG-CDF. The NG- CDF through the $290 \mathrm{NG-CDFs}$ is meant to attain rapid socio-economic development, start and implement prioritized projects which are community based in order to enhance community participation and guarantee that the gains are accessible to all the locals of a specific locality to improve the welfare of the people. The projects shall be in respect of national government functions that cover education and security. The two hundred and ninety NG- CDFs are allocated 2.5 per cent of the national revenue as decentralized funds. However, this led to emergence of bureaucracy in NGCDFs projects management, wanting performance and accountability 
questions. These unacceptable performances of NG-CDFs have been attributed to widespread corruption and poor financial management which results from dismal adherence to poor governance leadership practices (Okungu, 2008).

\section{Research Problem}

Various corporate financial scandals and the resultant business failures that include the Asian financial crisis of the late 1990s, Enron, WorldCom, Global Crossing and Tyco in the USA and Vivendi, Parmalat and others in Europe have made governance a major debate. The major global financial scandals and other inefficiencies were caused by poor corporate governance and weak internal audit which the Sarbanes Oxley Act of 2002, endeavored to address. There is consistent poor performance in organizations where budgets are not adhered to and conformity to the rules and regulations on the efficient utilization of finances and other resources leading to massive frauds and low efficiencies. This has made entities to undergo the risk of financial inadequacy and poor organizational performance resulting in undesirable service delivery (Mikes \& Kaplan, 2014). These scandals have resulted to queries on honesty and integrity among Corporate Boards and Executive Management.

Many state funds such as national Governance-Constituencies Development Funds (NG-CDFs) National Hospital Insurance Fund (NHIF), National Social Security Fund (NSSF), Youth Enterprises Development Fund, and Women Fund among others face financial crisis due to poor governance, fraud and corruption (Economic Report, 2019). The NG-CDF has spent billions of shillings since its dawn in 2004 (Auditor General Report, 2018). However, there has been public outcry because of immense financial scandals, fraud, corruption and poor performance by NG- CDFs. Okungu (2008) contends that 70 percent of the constituencies have noted misappropriation, stealing, fraud as well as exploitation, and that NG-CDFs matters are mostly have political inclination. Therefore, there was need to do this study to provide some tangible solutions.

The above challenges can be minimized through good governance. Empirically, studies on the relationship between governance and performance of NG-CDFs have not established authoritative relationship between the two variables. Most researches have concentrated on determining the relationship association between governance and organizational performance thus empirical gap. Also, it is evident that outcomes of these studies are conflicting. While some studies found out that good governance enhances performance (Tariq \& Abbas, 2013) others found that governance had an inverse relationship between governance and entity's performance (Price et al., 2011). There exist limited studies outside Kenya that have been carried out on governance and performance of NG-CDFs in Kenya. Contextually no studies 
outside Kenya have been carried out on governance and performance of NGCDFs in Kenya. There are studies on NG-CDFs in Kenya but none exist on the relationship between governance and performance of NG-CDFs in Kenya ((Malala \& Ndolo, 2014).Some studies used case study and longitudinal studies (Auyo \& Oino, 2013, Price et al., 2016) while others used one theory ( Hassan, 2012). Therefore, the current study addressed the gaps demonstrated along conceptual, contextual, methodological and theoretical by answering the question, what is the relationship between governance and NG-CDFs performance in Kenya?

\section{Literature Review \\ Theoretical Review}

The proponents of agency theory are Adam smith in $18^{\text {th }}$ century and tested by Ross (1973) as well as Jensen and Meckling (1976). The proponents of the theory assert that the separation of ownership from the owners results to an agency challenge in which management operates the company in accordance to their individual desires, and not the one's of shareholders (Jensen \& Meckling, 1976). It offers chances for leaders to utilize organization resources optimally to their utilities instead of amplifying the shareholder resources. The managers who usually have greater knowledge and proficiency about the organization have the privilege to address individual interests instead of those for shareholders (proprietor) concerns (Fama \&Jensen, 1983). This leads to principal agent conflict. Apart from the relationship of the principal and the managers, agency differences might occur between other stakeholders.

The theory suggests that organizational performance is improved through the shareholders' delegation of responsibilities to the professional managers with strong mechanism to monitor the performance of managers to register improved performance hence high return to the shareholders (Power, 2000). Modovean (2001) suggests that the owners should enact ratification, monitoring and sanctioning to guard against management failure. Two significant governance ways to solve or minimize the agent principal problem escalating from self-interest is through proper remuneration of board of directors and installation of governance structures to lower agency costs (Haniffa \& Hudaib, 2006).

Power (2000) suggests that the major way of monitoring is through the final annual accounts whose credibility is enhanced by the audit report. However, accounts might not be a sufficient tool for monitoring purpose as a result of information asymmetry whereby managers or external auditors doctor final results to conceal information fearing that it may be used against them. To be able to overcome information asymmetry bottleneck and protect their wealth, shareholders may install effective internal audit and internal controls. The internal audit and audit board produce audited financial 
statements and other reports assuring the owners about the development of their entity. Internal audit also monitors the management's activities and advices the board on the same. Similarly audit board enforce internal controls which ensure that the agents' activities are meant to improve the organizational performance. Organizational controls ensure compliance with the regulatory laws and regulations. Agency theory links to the variables of the research in the sense that the theory proposes that sound governance by the management through effective mechanism reduces agency costs, mitigate monitoring and cost resulting to general governance processes improvement, discretionary disclosure as well as enhancement performance of the firm (Siddiqui et al., 2013). Therefore, every NG-CDF should uphold good governance practices and tighten internal audit role to promote efficiency and eliminate incompetence, corruption, fraud and so on to enhance improved performance.Agency theory faces numerous criticisms and one of them is the analytical approach on how to handle the governance challenge which is limited to shareholders only and yet there are many stakeholders in the organization and thus its governance is affected by the relationship among these stakeholders.

Freeman (1984) was the first scholar who came up with Stakeholder theory and later developed by Donaldson. Stakeholder is a wide terminology that commonly alludes to category of persons who might influence directly or indirectly by attainment of the institution's aims and performance (Davis et al; 1997). Stakeholders include for example owners, employees, customers, NonGovernmental organizations, suppliers, the media, competitors, government, financial advisers, local community where the organization operates among others (Donaldson \& Preston, 1995).

The theory asserts that the owner is one of several equal stakeholders. Therefore, the focus of management decisions considers the interest of all stakeholders. Stakeholders can influence the reporting of an organization, structure and the financial policy. Their contributions and expectations should be considered in developing critical goals and objectives of the firm which eventually improves organizational performance

The stakeholder theory is relevant to NG-CDFs because the various stakeholders particularly the community provide land to NG-CDFs all over Kenya to build education and security institutions which provide education and security services respectively to all stakeholders. Furthermore, the communities disclose important information about criminals and dangerous groups which help the security forces to capture and hand them to the relevant authorities thus reduce criminology and ensure peace and harmony prevailed among the people. Similarly, other stakeholders for example the media highlights the operations and activities of criminals which assist the police in managing them hence boost security service delivery. Suppliers provide 
construction materials on credit to contractors hired by NG-CDFs to construct police posts, local administration offices and educational facilities thus boosting security and education services delivery. They also supply food on credit to learning institutions thus enabling the learners to be well fed which results to concentration in learning thus enhanced academic performance. In short, the participation of stakeholders in service delivery in NG-CDFs is paramount in enhancing performance.

The theory faces a number of criticisms. First, there is a challenge to identify genuine stakeholders (Smallman, 2004). Again meeting stakeholder interest is difficult as a result of variations in stakeholder values and expectations of the organization. Practically, it's difficult to handle all stakeholders equally as well have them effectively represented in corporate governance recommendations since it will underrate the welfare of the organization. Further, fulfilling stakeholders' interest opens a route for corruption, as it provides the managers the occasion to channel the resources away from owners to elsewhere.

\section{Empirical Review}

Some research studies have established positive relationship amongst governance and organizational performance (Rashid et al., 2008) while others found negative relationship Price et al., (2011). Good governance reduces management compensation (Bually et al., 2017) and the resources saved are used in revenue generating activities thus boosts organizational performance. On the other hand, good governance installs governance structures. These governance structures offer oversight role ensuring that resources are efficiently utilized leading to improved performance (Mallin, 2010). The proper use of resources and accountability result in enhanced organizational performance.

Tariq and Abbas (2013) studied the association between corporate governance practices and company performance in 119 listed companies from the period 2000 to 2010 applying multidimensional performance scheme. Their findings were clearly indicative of a notable effect of compliance on firm performance that is excellent corporate governance practices affect positively performance of the firm.

Tsamenyi et al. (2007) conducted a study to explore levels of compliance of all firms listed on the Ghana security exchange from 20012002. The researcher formulated a Ghanaian corporate governance index for 22 Ghanaian companies via corporate governance practice survey. The findings were an average disclosure and transparency score of $52 \%$.

Price et al. (2011) studied the relationship between governance practices and performance of the firms in Mexico. The study made use of 107 
firms for a period between 2000 and 2004. Their findings were that good corporate governance practices do not have impact on firm performance.

An assessment of the quality of corporate governance practices was done by Kalezic (2012) with respect to the basic principles OECD and corporate governance. Their influence was linked to performance firms in Montenegro. The findings depicted quality of corporate governance practice was associated positively with performance of firms. Auya and Oino (2013) examined the function of $\mathrm{CDF}$ in rural development, experiences from North Mugirango Constituency, Nyamira County, Kenya. The study employed quasi experiment research design to give qualitative and quantitative data required to respond to research hypothesis using questionnaire and interviews. The findings were that CDF had contributed significantly than ever before in provision of education and health services.

Malala and Ndolo (2014) examined the determinants for performance of constituency development funds projects in Kenya: a case study of kikuyu constituency. The study used quantitative and descriptive survey. The sample size was 80,000 registered voters and beneficiaries of the CDF projects out of the target population of 265,827 beneficiaries. The study found out that a variety of factors such as procurement process, entrepreneurial attitude of small medium enterprises participating in CDF projects procurement, governance and political interference, monitoring and evaluation and capacity of small and medium enterprises at constituency level to supply needs of CDF funded projects affected the performance of CDF projects in Kenya. Hassan (2012) studied the influence of stakeholder contribution on performance of CDFs projects in Isiolo North Constituency, Kenya. The study used a questionnaire and interviewed respondents from 155 projects with a total of 465 possible respondents. It also used stakeholder theory. The goal of the study was to determine the role of various stakeholders in performance of CDF funded projects and apply the findings to come up with measures or recommendations to strengthen the application of CDF funds. The study findings revealed a positive association among the stakeholders in performance of $\mathrm{CDF}$ funded projects. 


\section{Conceptual Framework}

Figure 2.1: Conceptual Model

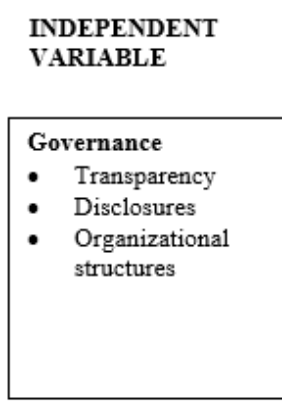

DEPENDENT VARIABLE

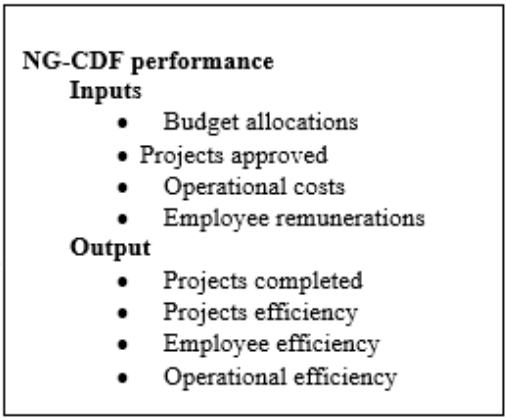

Source: Researcher (2020)

\section{Methodology}

This study adopted cross-sectional survey design which is ideal for this study since it has clearly stated hypotheses that determine relationships between independent and dependent variables (Cooper \& Schindler, 2006). The study is inclined to the positivism approach because it is theory based from which testable quantitative hypotheses are drawn for testing like similar studies by Aosa (1992). Positivism presumes that study is based on neutrality, real facts, consistency, validity and measurements of findings. It also assumes that the approach is methodologically quantitative and value free (Zikmund et al., 2010). The study was a census and the target population was the 290 NGCDFs in Kenya since the NG-CDFs are few but spread in the entire country, Kenya.The research study applied both secondary and primary mechanisms in data collection because both data reinforce each other (Cooper \& Schindler, 2006).Primary data was collected by self-administered, pre-arranged questionnaire which was prepared in line with the goals, theories upon which the study was anchored, empirical studies and corresponding hypotheses of the study. Either the chairperson or the secretary or the treasurer or the Fund account manager answered the questions resulting to one hundred and eight five respondents. Secondary data was easily accessible from the National Treasury, Kenya National Bureau of Statistics, the General Auditor's reports and NG-CDF website. Secondary data on performance of NG-CDFs was collected for the period 2014 to 2018 from NG-CDFs reports. An average of that data for the five years showing the performance of each NG-CDF was computed, analyzed and measured using DEA.

Descriptive analysis was conducted to measure the dispersion of variables such as standard deviation and coefficient of variation which were used to disclose the relationship of variables under study. Qualitative data was collected using Likert scale where content analysis was undertaken to determine the association of the independent variable with the dependent 
variable. R-squared was applied to test the strength of the overall relationship of the predictor variable in anticipating the dependent variable (Gujarat, 1992) that is governance and NG-CDFs performance in Kenya. The regression equation was presented as $Y=\beta_{0}+\beta_{1} X_{1}+\varepsilon$ Where: $Y=$ Performance of NGCDFs in Kenya; $\beta_{0}=$ Regression Constant, $\beta_{1}=$ Coefficients measured the change in a dependent variable with respect to a unit change in predictor variable holding other factors constant, $X_{1}=$ Governance and $\varepsilon=$ the error term / disturbance term. The p-value for the F-statistic was used to determine the robustness of the model. It was used to accept or reject the null hypothesis. The study tested hypotheses at $95 \%$ level of significance; subsequent decision points to reject or fail to reject a hypothesis were founded on the p-values. Where $\mathrm{p}<0.05$, the research rejected the null hypotheses, and where $\mathrm{p}>0.05$, the research failed to reject the null hypotheses. The findings are presented along study objectives and corresponding hypotheses.

\section{Results and Discussions \\ Response Rate}

The study targeted 280 respondents; however, the researcher received response from 185 respondents forming $66.07 \%$ response rate, which was found to be adequate. Njeru, (2013) proposes that a response rate of sixty percent is representative of the population of the study. Such a high response rate for this study can be as a result of the use of trained research assistants who were equipped with skills on how to build rapport with respondents.

\section{Descriptive Statistics for Governance}

Table 4.1 shows the descriptive statistic of the variables under study which include number, mean, standard deviation, coefficient of variation, $t$ test, and significance of governance. The relationship between variables was tested by descriptive and inferential statistics. Simple regression analysis was used to test the hypotheses at 95 percent confidence level.

The findings are presented in Table 4.1 in terms of mean scores, standard deviation, and coefficient of variation, $t$ statistics and significance values.

\begin{tabular}{|l|c|c|l|l|l|l|}
\hline \multicolumn{1}{|c|}{ Table 4.1: Governance } \\
\hline Transparency & $\boldsymbol{N}$ & Mean & Standard Deviation & CV \% & T & Sig. \\
\hline Disclosure & 185 & 3.34 & 1.05 & 33 & .017 & 0.174 \\
\hline Organizational structure & 185 & 3.42 & 1.068 & 31 & .830 & .000 \\
\hline
\end{tabular}

The average mean score of the statements depicting the manifestations of transparency as the sub-variable of governance was 3.34, standard deviation of 1.05 and $\mathrm{CV}$ of 33 percent The statements depicting disclosure gave an 
average mean score of 3.42, standard deviation of 1.068 and coefficient of variation of 31 .

The average mean score of the statements depicting the manifestations of organizational structure was 3.36, standard deviation of 1.121 and coefficient of variation of 34 percent.

\section{Performance of NG-CDFs in Kenya}

Data envelopment analysis was used to examine performance of NGCDFs in Kenya using input/output relationship. A decision-making unit where a score less than $100 \%$ is considered inefficient compared to other units. The findings are shown in Table 4.2.

Table 4 2: Performance of NG-CDFs in Kenya

\begin{tabular}{|l|l|l|}
\hline Range/Statistic & Frequency & Value \\
\hline 0.0 to 0.3 & 81 & $43.78 \%$ \\
\hline 0.31 to 0.6 & 85 & $45.95 \%$ \\
\hline 0.61 to 0.9 & 17 & $9.18 \%$ \\
\hline $0.91-1$ & 2 & $1.08 \%$ \\
\hline Mean & & 0.37368 \\
\hline Standard Error & & 0.0214 \\
\hline Median & & 0.333523 \\
\hline Mode & & 0.454532 \\
\hline Standard Deviation & & 0.182824 \\
\hline Sample Variance & & 0.025175 \\
\hline Kurtosis & & 0.063122 \\
\hline Skewness & & 0.543802 \\
\hline Range & & 0.94742 \\
\hline Minimum & & 0.05054 \\
\hline Maximum & & 1 \\
\hline Sum & & 105.8571 \\
\hline Count & & 185 \\
\hline Confidence Level (95.0\%) & & 0.032132 \\
\hline
\end{tabular}

Efficiency is defined as the ratio of outputs to the resources used/inputs. In the study, DEA Model inputs were: budget allocations, projects approved, operational costs incurred and employee remunerations. The outputs were: projects completed, projects efficiency, employee efficiency and operational efficiency. The findings shown in table 4.2 indicates that (45.95\%) of NG-CDFs were moderately inefficient with efficiency score of between 0.31 and 0.6 . It was also established that $43.78 \%$ of NG-CDFs were inefficient with efficiency score of 0.3 and below. Further findings indicate that the performance of $9.18 \%$ of NG-CDFs was above average with efficiency score ranging from 0.61 and 0.9 . Only 2 NG-CDFs representing $1.08 \%$ were found to be efficient with efficiency score of 1 . The mean 
efficiency score was 0.37368 which is below average. In order to increase efficiency, NG-CDFs should decrease the level of resources and investments and/or increase the production factors.

\section{Hypothesis Testing Results}

The first objective tested the following hypothesis; $\mathrm{H} 0$ : there is no significant relationship between governance and performance of NG-CDFs in Kenya. NG - CDFs performance (dependent variable) was regressed on governance (Independent variable). This was tested through the bivariate regression analysis and the relevant outcomes are shown in Table 4.3.

Table 4.3: Regression Results of Governance and NG-CDFs Performance

a) Goodness of Fit

\begin{tabular}{|c|c|c|c|c|c|c|c|}
\hline & \multicolumn{7}{|c|}{ Model Summary } \\
\hline $\begin{array}{c}\text { Mode } \\
l\end{array}$ & $\boldsymbol{R}$ & R Square & \multicolumn{2}{|c|}{ Adjusted R Square } & \multicolumn{3}{|c|}{ Std. Error of the Estimate } \\
\hline 1 & $.447^{\mathrm{a}}$ & .215 & \multicolumn{2}{|c|}{.202} & \multicolumn{3}{|c|}{.17543} \\
\hline \multicolumn{8}{|c|}{$A N O V A^{a}$} \\
\hline \multicolumn{2}{|c|}{ Model } & $\begin{array}{l}\text { Sum of } \\
\text { Squares }\end{array}$ & $D f$ & \multicolumn{2}{|c|}{ Mean Square } & $\boldsymbol{F}$ & Sig. \\
\hline \multirow[t]{3}{*}{1} & Regression & 1.895 & 1 & \multicolumn{2}{|r|}{1.895} & $\begin{array}{c}49.86 \\
8\end{array}$ & $000^{\mathrm{b}}$ \\
\hline & Residual & 6.901 & 181 & \multirow{2}{*}{\multicolumn{2}{|c|}{.038}} & & \\
\hline & Total & 8.796 & 182 & & & & \\
\hline \multicolumn{8}{|c|}{ Coefficients } \\
\hline \multirow{2}{*}{\multicolumn{2}{|c|}{ Model }} & \multicolumn{2}{|c|}{$\begin{array}{c}\text { Unstandardized } \\
\text { Coefficients }\end{array}$} & \multirow{2}{*}{\multicolumn{2}{|c|}{$\begin{array}{c}\text { Standardized } \\
\text { Coefficients } \\
\text { Beta }\end{array}$}} & \multirow[t]{2}{*}{$T$} & \multirow[t]{2}{*}{ Sig. } \\
\hline & & $\boldsymbol{B}$ & Std. Error & & & & \\
\hline \multirow[t]{2}{*}{1} & (Constant) & .286 & .017 & & & 16.824 & .000 \\
\hline & Governance & .049 & .007 & \multicolumn{2}{|c|}{.398} & 7.062 & 000 \\
\hline
\end{tabular}

a. Dependent Variable: Performance (Efficiency Score)

b. Predictors: (Constant), Governance

The study established a relatively moderate relationship between governance and performance of NG-CDFs in Kenya $(\mathrm{R}=.447)$. Coefficient of determination $\left(\mathrm{R}^{2}=.215\right)$ shows that governance explains $21.5 \%$ of variation in performance of NG-CDFs in Kenya with the remaining $78.5 \%$ being explained by other variables implemented by NG-CDFs and not considered in the model. However, although moderate, the relationship is significant $(\mathrm{F}=49.868, \mathrm{p}<0.05)$.

The significant association is further manifested by the $\mathrm{t}$-value in the coefficient table $(\beta=.049, \mathrm{t}=7.062, \mathrm{p}<0.05)$. This therefore depicts that governance is key in determining performance of NG-CDFs in Kenya and thus the hypothesis that there is no significant relationship between governance 
and performance of NG-CDFs in Kenya was rejected and the alternative hypothesis that there is significant relationship supported.

Founded on the outcomes of the regression results analysis as presented in Table 4.3, the model becomes; $\mathrm{Y}=0.286+0.049 \mathrm{X}_{1}$

Where $\mathrm{Y}$ was NG-CDFs performance and $\mathrm{X}_{1}$ is Governance. This means that a single change in governance produces 0.049 changes in performance of NG-CDFs. However, when governance is held constant, performance is 0.286 units as represented by a constant value $\left(\beta_{0}\right)$. This implies that governance significantly adds to performance of NG-CDFs in Kenya. This was guided by the model represented as; Objective 1: $\mathrm{Y}_{\mathrm{i}}=\beta_{0}+$ $\beta_{1} X_{1}+\varepsilon$. Where: $Y_{i}$ is NG-CDFs performance; $X_{1}$ is governance; $\beta_{0}$ and $\beta_{1}$ are the coefficients of determination and $\varepsilon$ is the error or disturbance term to represent omitted variables.

\section{Summary and Conclusion}

The first hypothesis $\left(\mathrm{H}_{1}\right)$ explored the relationship between governance and performance of $\mathrm{NG}=\mathrm{CDFs}$ in Kenya. Findings of simple regression indicate that there is a significant and positive relationship $(\mathrm{R}=0.447, \mathrm{R} 2=0.215, \mathrm{~F}=49.868 \mathrm{p}<0.05)$ between governance and performance of NG-CDFs in Kenya leading to the rejection of null hypothesis and accepting the alternative hypothesis. The rejection of the null Hypothesis $\left(\mathbf{H O}_{1}\right)$ and accepting the alternative hypothesis which explored the association between governance and performance of NG-CDFs in Kenya ascertained that governance had a significant remarkable effect on performance. Governance accounted for 21.5 percent of performance of NG-CDFs in Kenya that is explaining 21.5 percent variation of performance of NG-CDFs in Kenya. The results anchor in literature the importance of governance in influencing performance of NG-CDFs in Kenya. From policy perspective, the study findings demonstrate that governance is practiced in all the NG-CDFs. The study investigated the relationship between governance and NG-CDFs performance in Kenya and the results were positive and significant.

\section{Recommendations}

Based on the findings the regulating authorities such as Parliament, Auditor General, and Non -Governmental Organizations among others should hold the NG-CDFs to account for their performance. At policy level the NGCDF board should ensure that all NG-CDFs have homogeneous governance practices and adherence to internal control mechanisms that ensure enhanced performance. Managerial practitioners especially in NG-CDF may consider strengthening governance to enhance performance. The study also, recommends that policy makers to review the entire performance measurement tool and process in the NG-CDFs to verify that the results 
reported reflect the situation on the ground. In this case the NG-CDFs should use Data Envelopment Analysis (DEA) in measuring performance. The study can also be used in different contexts in order for researchers to draw different patterns showing the effect of governance on organisational performance outcome. In addition, future studies need to use similar variables in the other funds such as youth fund, women fund among others.

\section{References:}

1. Aosa E. (1992). An empirical investigation of aspects of strategy formulation an implementation within large private manufacturing companies in Kenya, PhD Thesis. University of Strathclyde, Glasgow.

2. Arena, M., Azzone, G., \& Bengo, I. (2015). Performance measurement for social enterprises. VOLUNTAS: International Journal of Voluntary and Nonprofit Organizations, 26(2), 649-672.

3. Armstrong, A, Jia, X \& Totikidis, V. (2005). Parallels in Private and Public Sector Governance, GovNet Annual Conference, Contemporary Issues in Governance. Paper presented to GovNet Annual Conference, Contemporary Issues in Governance Melbourne, 28-30 November.

4. Auya, S. \& Oino, P. (2013). The Role of Constituency Development Fund in Rural Development: Experiences from North Mugirango Constituency, Nyamira County, Kenyan. International Journal of Science and Research (I.J.S.R). 2(6), 306-312.

5. Braadbaart, O. (2007). Collaborative Benchmarking, Transparency and Performance: Evidence from the Netherlands Water Supply Industry. Benchmarking: An International Journal, 14(6), 677-92.

6. Buallay, A., Hamdan, A. \& Zureigat, Q. (2017). Corporate Governance and Firm Performance: Evidence from Saudi Arabia, Australasian Accounting, Business and Finance Journal, 11(1), 2017, 78-98. doi:10.14453/aabfj.v11i1.6

7. Bushman, R. M., Piotroski, J. D., \& Smith, A. J. (2004). What determines corporate transparency? Journal of Accounting Research, 42(2), 207-252.

8. Cooper, R.D. \& Schindler, S.P. (2014). Business Research Methods. $12^{\text {th }}$ Edition. New York: McGraw Hill

9. Davis, J., Donaldson, L. \& Schoorman, D. (1997). Towards A Stewardship Theory of Management, Academy of Management Review 1997, Vol. 22 No. 1, 20-47

10. Donaldson, L. \& Davis, J. (1991). Stewardship Theory or Agency Theory: CEO Governance and Shareholder Returns. Australian Journal of Management, 16(1), 49-64. 
11. Donaldson, T \& Preston, L. E. (1995). The Stakeholder Theory of the Corporation: Concepts, Evidence and Implications. Academy of Management Review, 20(1), 65-91.

12. Economic Survey (2019). Kenya National Bureau of Statistics. The Popular Version. Series No.1/2019

13. Emrouznejad, A., Anouze, A. L., \& Thanassoulis, E. (2010). A semioriented radial measure for measuring the efficiency of decision making units with negative data, using DEA. European Journal of Operational Research, 200(1), 297-304.

14. Fama,E.\&Jensen, M.(1983).Separation of Ownership and Control. Journal of Law and Economics, 26(2), 301-325.

15. Formentini, M., \& Taticchi, P. (2016). Corporate sustainability approaches and governance mechanisms in sustainable supply chain management. Journal of Cleaner Production, 112, 1920-1933.

16. Freeman, R. E., Wicks, A. C., \& Parmar, B. (2004). Stakeholder Theory and "The Corporate Objective Revisited". Organization Science, 15(3), 364-369.

17. Freeman, R.E. (1984). Strategic Management: A Stakeholder Approach. Boston: Pitman Publishing.

18. Gok, (2016). Report on evaluation of the performance of public agencies for the financial. Economic Development Report April. Nairobi: Government Printers.

19. Gujarati, D \& Porter, D. (1992). Essentials of Econometrics. New York: McGraw-Hill.

20. Haniffa, R.\&Hudaib,M. (2007).Locating Audit Expectations Gap within a Cultural Context: The Case of Saudi Arabia. Journal of International Accounting, Auditing and Taxation, 16(2), 179-206.

21. Hebb, T. (2006). The economic inefficiency of secrecy: Pension fund investors' corporate transparency concerns. Journal of Business Ethics, 63, 385-405.

22. Jensen, M. \& Meckling, W. (1976). Theory of the Firm: Managerial Behavior, Agency Costs and Ownership Structure. Journal of Financial Economics, 3(4), 305-360.

23. Kalezić, Z. (2012). Corporate governance and firm performance with special reference to the banking system: empirical evidence from Monetengro. Journal of Central Banking Theory and Practice, 2, 1954.

24. Khan, N. I. \& Rahim, N.H.A. (2016). Firm performance: An empirical study on timeliness of financial reporting and financial voluntary disclosure. E-academia Journal, 55(1). 
25. Malala, A.J \& Ndolo J. (2014). Factors affecting performance of Constituency Development Fund Projects in Kenya: htpp://www.researchgate.net/publication/281590305.

26. Mallin, C.A. (2010). Corporate governance, $3^{\text {rd }}$ edn, New York: Oxford UniversityPress.

27. Mikes, A., \& Kaplan, R. S. (2014). Towards a contingency theory of enterprise risk management. Working Paper, 13-063.

28. Modoveanu, \& Mihrea (2001). Agency Theory and the Design of an Efficient Governance Mechanism. Minnesota: Rotman School of Management, University of Minnesota.

29. McGee, R.W. \& Yuan, X. (2009). 'Corporate governance and the timeliness of financial reporting: An empirical study of the people's Republic of China', International Journal of Business, Accounting and Finance, 3(1), 19-27.

30. Njeru, W. G. (2013). Market orientation, marketing practices, firm characteristics, external environment and performance of tour firms in Kenya. Unpublished Doctoral Thesis. Nairobi: University of Nairobi

31. Okiro, K.O. (2014). Corporate governance, capital structure, regulatory compliance and performance of firms listed at the East African Community Exchange. Unpublished PhD Thesis, University of Nairobi.

32. Okungu, J, (2008). The beauty and shame of Kenya's Constituency

Development Fund. [Online] Available:

http:/www.afroarticles.com/article-

dashboardarticle.php?id=6337\&act=print.

33. Organization for Economic Co-operation and Development (2004), "OECD Principles of Corporate Governance. Paris: Press.

34. Power, M. (2000). The Audit Implosion: reporting risk from the Inside. London: ICAW.

35. Price, R., Román, F. J. \& Rountree, B. (2011). The impact of governance reform on performance and transparency. Journal of Financial Economics, 99(1), 76-96.

36. Republic of Kenya (2003). Public Audit Act. Nairobi: Government Printer.

37. Republic of Kenya (2013). CDF Act. Nairobi. Government Printers.

38. Republic of Kenya (2015).NG-CDF Act. Nairobi. Government Printers.

39. Republic of Kenya (2016). NG-CDF Act. Nairobi. Government Printers.

40. Republic of Kenya, (2013). IEBC voter register. Nairobi: Government Printers. 
41. Republic of Kenya, (2019). Economic Development Report April. Nairobi: Government Printers.

42. Ross, S.A. (1973). The economic theory of agency: the principal's problem. American Economic Review, 63(2), 134-139.

43. Sarbanes - Oxley Act (2002). Corporate and auditing and accountability, Responsibility and transparency act of 2002, Us public law $107-20417^{\text {th }}$ congress, $2^{\text {nd }}$ session, July 30.

44. Semmar, A. (2012). Corporate governance of state-owned enterprises in morocco: evolution and perspectives. In OECD, Towards New Arrangements for State Ownership in the Middle East and North Africa, OECD Publishing. doi: 10.1787/9789264169111-8-en

45. Smallman, C. (2004). Exploring Theoretical Paradigm in Corporate Governance. International Journal of Business Governance and Ethics, 1(1), 78-94.

46. Tariq, Y. \& Abbas, Z. (2013). 'Compliance and Multidimensional Firm Performance: Evaluating the Efficacy of Rule-Based Code of Corporate Governance', Economic Modelling, 35, 565-

47. Tavana, M., Kaviani, M. A., Di Caprio, D., \& Rahpeyma, B. (2016). A two-stage data envelopment analysis model for measuring performance in three-level supply chains. Measurement, 78, 322-333.

48. World Bank (1992). Governance and Development. WashingtonD.C. WorldBank.

49. Zikmund, W. G., Babin, B. J., Carr, J. C. \& Griffin, M. (2010). Business Research Methods, $8^{\text {th }}$ ed. South-Western: Cangage Learning. 